5. Клименко М.О., Статник I.I. Охорона водних об'єктів від антропогенного впливу. Вісник КНУ імені Михайла Остроградського. Кременчук, 2010. Вип. 6/2010 (65). Ч. 1. С. 177-181.

6. Клименко М.О., Гроховська Ю.Р. Порівняльна характеристика результатів оцінки якості води за гідрохімічними показниками та водною рослинністю. Вісник РДТУ. Рівне, 2001. Вип. 3(10). С. 15-22.

7. Клименко М.О., Гроховська Ю.Р. Відновна гідроекологія порушених річкових та озерних систем (гідрохімія, гідробіологія, гідрологія, управління). Рівне, 2004. - 211 с.

DOI https://doi.org/10.30525/978-9934-26-183-1-9

\title{
ОСОБЛИВОСТІ ФІЗІОЛОГІЧНОГО СТАНУ EICHHORNIA CRASSIPES (MART.) SOLMS. ЗА РІЗНИХ ТЕМПЕРАТУР СЕРЕДОВИЩА
}

\author{
Красюк Ю. М. \\ кандидат біологічних наук, \\ науковий співробітник \\ Інститут гідробіології Національної академії наук Украӥни \\ м. Київ, Украӥна
}

Водяний гіацинт або ейхорнія (Eichhornia crassipes) через свої особливості може використовуватись в різних сферах призначення. Так, ейхорнія має високий вміст білку, що дає можливість застосовувати ії як сидерат, компост і мульчу для поліпшення грунту. Багато досліджень було присвячено використанню цієї рослини в якості кормового матеріалу для худоби [9, с. 965-972; 11].

Eichornia crassipes, через здатність інтенсивно поглинати та накопичувати нітрати, фосфати, феноли, тяжкі метали та інші шкідливі речовини, використовується для очищення забруднених вод [1, с. 48-50; 6, с. 155-160].

Ейхорнія росте у прісних водоймах (мілководні ставки, болота, невеликі струмки, озера та річки) за умови, що вони не засолені або не стають солоними під час посухи. Найсприятливіші температурні умови - від 14 до $29^{\circ} \mathrm{C}$, а перешкоджають ії розвитку - температури нижче $13^{\circ} \mathrm{C}[7]$. 
У зв'язку з тим, що водяний гіацинт є чутливим до зниження температури середовища, виникає необхідність дослідити наскільки різний температурний режим забезпечить оптимальність протікання процесу вегетації рослин протягом року в штучних умовах. Слід зазначити, що достатньо важливу роль у вирощуванні E.crassipes відіграє енергетичний стан рослин. Відома здатність водяного гіацинту зберігати вуглеводи в основі стебла, щоб використовувати як запас енергії під час стресу [8]. В забезпеченні нормального протікання метаболічних енергетичних процесів в організмі рослин E.crassipes, крім вуглеводів, приймають безпосередню участь білкові та ліпідні субстрати [3, c. 416].

Отже, метою даного дослідження було оцінити фізіологічний стан E.crassipes за розподіленням і вмістом енергетичних субстратів у тканинах рослин за впливу різних температур середовища.

Для дослідження фізіологічного стану ейхорнії за впливу різних температур використовували акваріуми об'ємом 50 дм $^{3}$ при інтенсивності освітлення $440 \mathrm{~lx}$, фотоперіоду - 14C:10Т. Щільність посадки рослин була 12 екз./ $\mathbf{M}^{2}$ при рівні води $23 \mathrm{cm.} \mathrm{Температурний}$ режим (вода і повітря) в акваріумах 1 і 2 становив $20 \pm 1^{\circ} \mathrm{C}$ та $26 \pm 1^{\circ} \mathrm{C}$, відповідно.

Величина $\mathrm{pH}$ складала в середньому 7,5, концентрація $\mathrm{O}_{2}-$ 7,1 мг/дм ${ }^{3}$, вміст $\mathrm{NH}_{4}{ }^{+}-0,9$ мг $\mathrm{N} /$ дм $^{3}, \mathrm{NO}_{2}{ }^{-}-0,2$ мг $\mathrm{N} /$ дм$^{3}, \mathrm{NO}_{3}{ }^{-}-2,7$ мг $\mathrm{N} /$ дм$^{3}, \mathrm{PO}_{4}{ }^{3-}-22,7$ мг $\mathrm{P} /$ дм$^{3}$. Якість водного середовища визначалась аналітичними методами [2, 376 с.].

Досліджували вміст загального білку і ліпідів у різних тканинах Eichornia crassipes (листя, стебло, коріння) [5, с. 352]. Отримані результати оброблено статистично із застосуванням t-критерію Стьюдента за допомогою програми Statistica 10.

Як показали наші попередні дослідження, при температурі води $20 \pm 1{ }^{\circ} \mathrm{C}$ розвиток E. crassipes відбувався повільніше, ніж за більш високої температури $\left(26 \pm 1^{\circ} \mathrm{C}\right)$. Зокрема, при утриманні ейхорнії в штучному гідрофітному модулі за температури води $26 \pm 1^{\circ} \mathrm{C}$ відмічено тривалий стабільний розвиток та інтенсивне вегетативне розмноження шляхом формування первинних і вторинних столонів. При цьому, за умов більш низької температури $\left(20 \pm 1^{\circ} \mathrm{C}\right)$ у рослин не спостерігалось інтенсивного росту, розвитку і розмноження, хоча вегетація рослин помірно стабільно тривала протягом всього періоду [4, С. 62-64]. Результати дослідження енергетичного стану E. Crassipes показали відмінності за вмістом білкових та ліпідних субстратів у листі, стеблі та корінні при різних температурних режимах середовища. (рис. $1, a, 6$ ) 


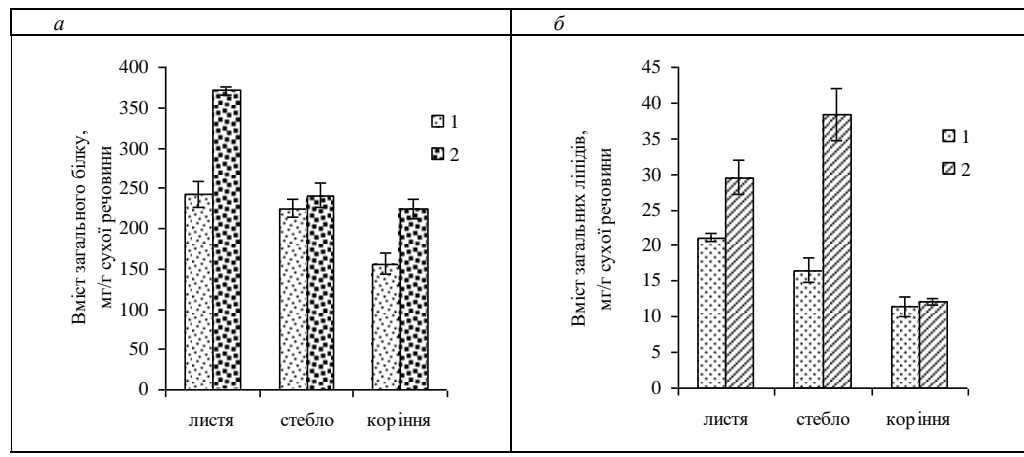

\section{Рис. 1. Вміст загального білку (a) та ліпідів (б) у Eichornia crassipes за впливу різних температур середовища, $M \pm m, n=3$}

Примітка: 1 -температура $20 \pm 1^{\circ} \mathrm{C} ; 2-$-температура $26 \pm 1^{\circ} \mathrm{C}$.

Зокрема, у E.crassipes за температури оточуючого середовища $26 \pm 1^{\circ} \mathrm{C}$ було виявлено вищий вміст загального білку у листі та корінні (на 35 і $30 \%$, відповідно), ніж у рослин за $20 \pm 1^{\circ} \mathrm{C}$ утримання (рис. $1, a$ ). Вірогідно, процес синтезу і накопичення білкового субстрату при більш високій температурі середовища відбувався більш активно.

Результати дослідження показали, що при утриманні E.crassipes при різних температурах води рівень загальних ліпідів у тканинах рослин відрізнявся. Так, вміст досліджуваного енергетичного субстрату у листі та стеблі ейхорнії при $26 \pm 1^{\circ} \mathrm{C}$ був достовірно вищим на 30 і $55 \%$, відповідно, порівняно з рослинами при $20 \pm 1^{\circ} \mathrm{C}$ (рис. $1, \sigma$ ). При цьому, у корінні рослин за впливу обох температур відмічено низький вміст загальних ліпідів, порівняно з листям і стеблом, що не суттєво відрізнявся по своїй величині. Слід зазначити, що ця тканина не $\epsilon$ основним депо ліпідів, а відповідає за постачання поживних речовин до організму E. crassipes, що підтверджується літературними даними інших дослідників [10, p. 65-70].

Про більш високий енергетичний потенціал ейхорнії при температурі $26 \pm 1^{\circ} \mathrm{C}$ порівняно 3 рослинами при $20 \pm 1^{\circ} \mathrm{C}$ свідчать результати дослідження середньої величини показників вмісту енергетичних субстратів. Зокрема, середній вміст загального білку у досліджуваних тканинах ейхорнії при вищій температурі середовища був більше на $25 \%$ та загальних ліпідів - на $41 \%$ порівняно 3 піддослідними, які знаходились при нижчій температурі. 
Таким чином, виявлено, що при температурі середовища $26 \pm 1{ }^{\circ} \mathrm{C}$ Eichornia crassipes має більш високий енергетичний потенціал порівняно з рослинами при $20 \pm 1^{\circ} \mathrm{C}$.

Рівень вмісту загального білку і ліпідів у тканинах рослин водяного гіацинту може бути інформативним показником фізіологічного стану їх організму.

\section{Література:}

1. Васенков Г.І., Василюк Т.П., Буднік І.П. Очищення стічних вод сільськогосподарського походження за участю Eichornia crassipes. Наук. зап. Терноп. нац. пед. ун-ту. Сер. Біол., 2010, 2 (43). С. 48-50.

2. Лурье Ю.Ю. Унифицированные методы анализа вод. М.: Химия, 1973. $376 \mathrm{c}$.

3. Макрушин М. М., Макрушина С. М., Петерсон Н. В., Мельников М. М. Фізіологія рослин. За ред. проф. М. М. Макрушина. Підручник. Вінниця: Нова Книга, 2006. 416 с.

4. Медовник Д. В., Крот Ю. Г., Красюк Ю. М., Левицька О. В., Кудрявцева Д. О. Особливості функціонування водного гіацинту Eichhornia crassipes (Mart.) Solms. в штучному гідрофітному модулі. Проблеми та перспективи розвитку сучасної біології та біологічної освіти: зб. наук. праць. Житомир, 2021. С. 62-64.

5. Рогожин В.В., Рогожина Т.В. Практикум по физиоогии и биохимии растений. Учеб. пособие. СПб.: ГИОРД, 2013. 352 с.

6. Флорик Е.А., Абрамович О.В., Змитрович А.А. Использование Eichornia crassipes для очистки сточных вод и получения кормовой добавки. Труды БГТУ. Химические технологии, биотехнология, геоэкология. 4. 2014. С. 155-160.

7. Hasan M. R., Ch akrabarti R. Use of algae and aquatic macrophytes as feed in small-scale aquaculture: FAO Fisheries and Aquaculture technical paper, 531, Rome, Italy, 2009. URL: http://www.fao.org/docrep/ 012/i1141e/i1141e00.htm

8. Madsen J. D., Luu K. T., Getsinger K. D. Allocation of biomass and carbohydrates in waterhyacinth (Eichhornia crassipes): pond-scale erification. Technical Report A-93-3. US Army Corps of Engineers Waterways Experiment Station Vicksburg, MS, 1993.

9. Mekuriaw S., Tegegne F., Tsunekawa A. Effects of substituting concentrate mix with water hyacinth (Eichhornia crassipes) leaves on feed intake, digestibility and growth performance of Washera sheep fed rice straw-based diet. Trop Anim Health Prod, 50.2018. P. 965-972. URL: https://doi.org/10.1007/s11250-018-1519-5 
10. Okoye P.C., Daddy F., Jlesanmj B.D. The nutritive value of water hyacinth (Eichhornia crassipes) and its utilisation in fish feed. Proceedings of the International Conference on Water Hyacinth. New Bussa, Nigeria. 2000. P. 65-70. URL: http://hdl.handle.net/1834/18855

11. Huazhu Y., Yingxue F., Zhonglin Ch. Integrated farming systems. In: Integrated agriculture-aquaculture: FAO Fisheries Technical Paper, 407, Rome, Italy. 2001. URL: http://www.fao.org/DOCREP/005/Y1187E/ y1187e08.htm

DOI https://doi.org/10.30525/978-9934-26-183-1-10

\title{
ВПЛИВ СПОЛУК НЕОРГАНІЧНОГО НІТРОГЕНУ НА ПЛОДЮЧІСТЬ ТА ГЕМОПОЕЗ DАРНNIIDAЕ
}

\author{
Кудрявцева Д. О. \\ аспірантка \\ Інститут гідробіології Наџіональної академії наук Украӥни \\ Костюк К. В. \\ кандидат біологічних наук, \\ старший науковий співробітник відділу екологічної фізіології \\ гідробіонтів та біотехнології \\ Інститут гідробіології Національної академії наук України
}

\section{Коновець І. М.}

кандидат біологічних наук, завідувач лабораторії біологічно активних сполук відділу екологічної фізіології гідробіонтів та біотехнології

Інститут гідробіології Національної академії наук України м. Київ, Україна

Розробка методів та технології масового культивування представників родини Daphniidae викликають широкий інтерес, оскільки вони є живим кормом для ранніх стадій промислово значимих видів риб, а також перспективними об'єктами для отримання біологічно активних сполук, у тому числі хітозану.

Підвищення продуктивності систем культивування пов'язане 3 необхідністю підтримки високих показників росту і відтворення гідробіонтів при максимальних показниках щільності посадки. 